\title{
奥地山村における青年男子従業者の就業過程 一岐皁県郡上郡和良村を事例として一
}

\author{
梶田 真（東京大学大学院生）
}

\begin{abstract}
奥地山村の地域経済は公共部門への依存によって特徵づけられる. 本研究では岐阜県和良村における青年 男子の就業過程として移動および職業歴を調查し，奥地山村における職業構造を分析した. その結果，後継 者などを除くと村内の職業は従業員の現職就業年齢と学歴によって 3 グループに分類されることが明らかに なった. 第 1 の役場・農協の事務職員のグループは現職就業年齢が最も若く, 学歴は最も高い. このグルー プは高貨金と福利厚生制度の充実によって特徴づけられる．第 2 の建設業・誘致工場労務職のグループは現 職就業年齢の面では役場・農協の事務職員のグループに準じるが, 学歴は低い. そして第 3 の中小工場労務 職のグループは現職就業年齢が著しく高い. また高齢従業員の引退に伴う青年労働力の更新が可能になって いるのは役場・農協の事務職員のグループのみで, 他の二つのグループは労働力不足の問題が深刻化しつつ ある.

キーワード : 奥地山村, 就業過程, 公共部門
\end{abstract}

\section{I 研究の目的}

過疎法1の成立によって過疎という考え方が政策 的に採用されてから，四半世紀が過ぎようとしてい る. 過疎法では (1) 雇用の創出による人口の維持, （2）生活環境の整備と公共サービス水準の引上げ が政策目標とされた：雇用創出の手段として用いら れたのが, 当時すでに都市部から農村部へと移転し つつあった労働集約型製造業の誘致に対する政策的 支援と巨額の公共投資の実施であった。 また公共サ 一ビス水準の引上げに伴って, 公共サービスでの雇 用も人口維持において重要な役割を果たすことにな った.とりわけ奥地山村や離島など地理的隔絶性の 高い地域では建設業や公共サービスが地域の基幹産 業として機能してきた。

モータリゼーションの浸透した今日, ある程度の 規模を持つ都市への通勤圈内にある農山村では就業 機会の問題はかってほど大きな問題ではなくなって きているが，そのような都市を近隣に持たない奥地 山村や離島では依然として雇用機会の確保は重要な 問題である. 財政支出に支えられた地域経済の形成 に対しては, 労働集約型製造業の地方分散化の動き
とともに, 経済成長の見返りに都市資本への従属性 を強めることになったとして「発展なき成長」(安 東 1986)，「周辺化」(岡橋 1990) といった表現で とらえられている. しかしこうした評価はともかく， 財政支出が地域人口維持において大きな役割を果た してきたことは事実である.

建設業や公共サービス雇用を分析する際のアプロ 一チには産業立地からの分析と地域労働市場からの 分析との二つが考えられる.

産業立地からのアプローチでは，公共投資に支え られた建設業において多くの研究蓄積が見られる (斎藤・木曾 1964 ; 三浦 1977 ; 藤田・友国 1979 ; 岡橋 1980，1982；田島・村上 1985 ; 小木曽 1986). これに対して, 役場をはじめとする公共サービス雇 用に関する研究は少なく, 筆者の知る限りでは公共 サービス雇用を直接のテーマとした実証研究は見あ たらないが, 安東 (1986) は「人口 5000 人以下く らいの過疎村」において公共サービス雇用の役割が 大きいことを指摘し，「島の自治と自立」と題され た第 7 回自治体学会・第 4 分科会では, 人口 208 人中役場職員が 33 名を占める東京都青ヶ島村など の極限の自治の実情が報告された（自治体学会・第 
4 分科会 1993)。 また篠原（1991）は, 市に合併さ れた旧町村で最も深刻な人口減少が起きていること を指摘し, その理由として旧町村の公共施設の吸 収・廃止に伴う生活利便性の低下と雇用の靠失を挙 げている.

一方, 地域労働市場からのアプローチでは, 農業 の省力化によって生じた中高年男性の農家余剩労働 力が日雇建設雇用によって吸収されていることが, 農業集落への世帯調査の結果から明らかにされてい る(岡橋 1980 ; 小木兽 1986).

地域労働市場の中で建設業や公共サービス雇用の 賃金水準は高く, とりわけ公共サービス雇用は年功 賃金制の存在によって右肩上がりの年齢一賃金カー ブを描く数少ない存在である（岡橋 1982 ; 田代 1993).このような雇用の創出は新規学卒やU夕ー ンの青年男子を地域に定着させる上で大きな役割を 果たしていることが指摘されている（安東 1986） ものの, 実証研究は十分に行われていない. その原 因は，これまでの世帯を対象とした就業構造調査か らは, 構成比率の低い青年男子のサンプルを十分に 得ることが出来ないためであると思われる.

また, 山村振興法や過疎法が成立し地域労働市場 の変化が盛んに議論された 1970 年代後半から 1980 年代前半に比べ, 近年の就業動向を報告した研究は 少ない. しかし, 高度経済成長期に農村部に滞留し た世代の高齢化や公共投資政策の後退などの近年の 動きによって, 地域労働市場は再編を迎えつつある.

本研究ではこれらの点を踏まえた上で, 奥地山 村2)の一事例として岐阜県郡上郡和良村を調查地域 として取り上げ, 村内の各事業所の労働力編成およ び青年男子従業者の就業過程に関する調査を行った. 本研究における就業過程とは従業者の移動歴と職業 歴を指している. 今日の奥地山村では他出経験者な いしは他地域出身者の従業者が多くなっており, 現 職に至るまでのプロセスの分析は就業動向を考える 上で必要不可欠な要素であると考えられる. さらに
この従業者の就業過程の面から同村内の職業構造を 分析し, 民間他産業との比較を踏まえて, 建設業や 公共サービス雇用の特性について考察する.

\section{II 対象地域と調査の概要}

和良村は長良川流域と飛驒川流域に挟まれた山村 であり（図 1 ), 村域 $100.19 \mathrm{~km}^{2}$ に対し人口は 2459 人（1995 年国勢調查）である. 長良川沿いの国道 156 号線之飛驒川沿いの国道 41 号線との間を金山 町から和良村を経て八幡町へと至る旧県道 61 号線 が基幹道路であり，1993 年に国道 256 号線に指定 された．和良村の中心部から金山町までは 20 分, 八幡町までは 30 分ほどの距離にある．こうした交 通条件の中で和良村の全就業者中，八幡町へ $9.2 \%$, 金山町に 7.6\%（1995 年国勢調查速報値）が通勤し ているが，最寄りの都市である美濃市までは東海北 陸自動車道が開通した現在でも 1 時間近くかかり, 就業機会は限定されている.

図 2 は, 和良村の産業構造を把握する上で, 高齢 者の自給生産的性格の強い農業就業者を除外するた めに 60 歳未満に限定して, 従業地による産業別就 業者数を図示したものである．和良村は山間部に位 置するため農業経営規模が零細で, 林業も人工林化 が遅れたため，第一次産業の比重は小さい．また観 光資源がそしく, 分水嶺の太平洋側に位置するため, 降雪量の面からスキー場の設置も不可能である. 観 光産業として挙げられるのは，わずかに和良川での 鮎の渓流釣り程度である．その一方で村立病院を経 営し, 病院職員は村の職員であるため, 公共サービ スの経済的比重は大きい，現在の和良村の村内産業 を支えているものとしては，財政支出に依存した建 設業と公共サービスのほかに製造業が挙げられる.

製造業・建設業・公務を合わせた就業者の割合は $59 \%$ にのぼり，これに公共サービスに属するサー ビス業就業者を加えると，その割合は $70 \%$ 程度と なる3)。とりわけ製造業就業者の大半が単純労務職 

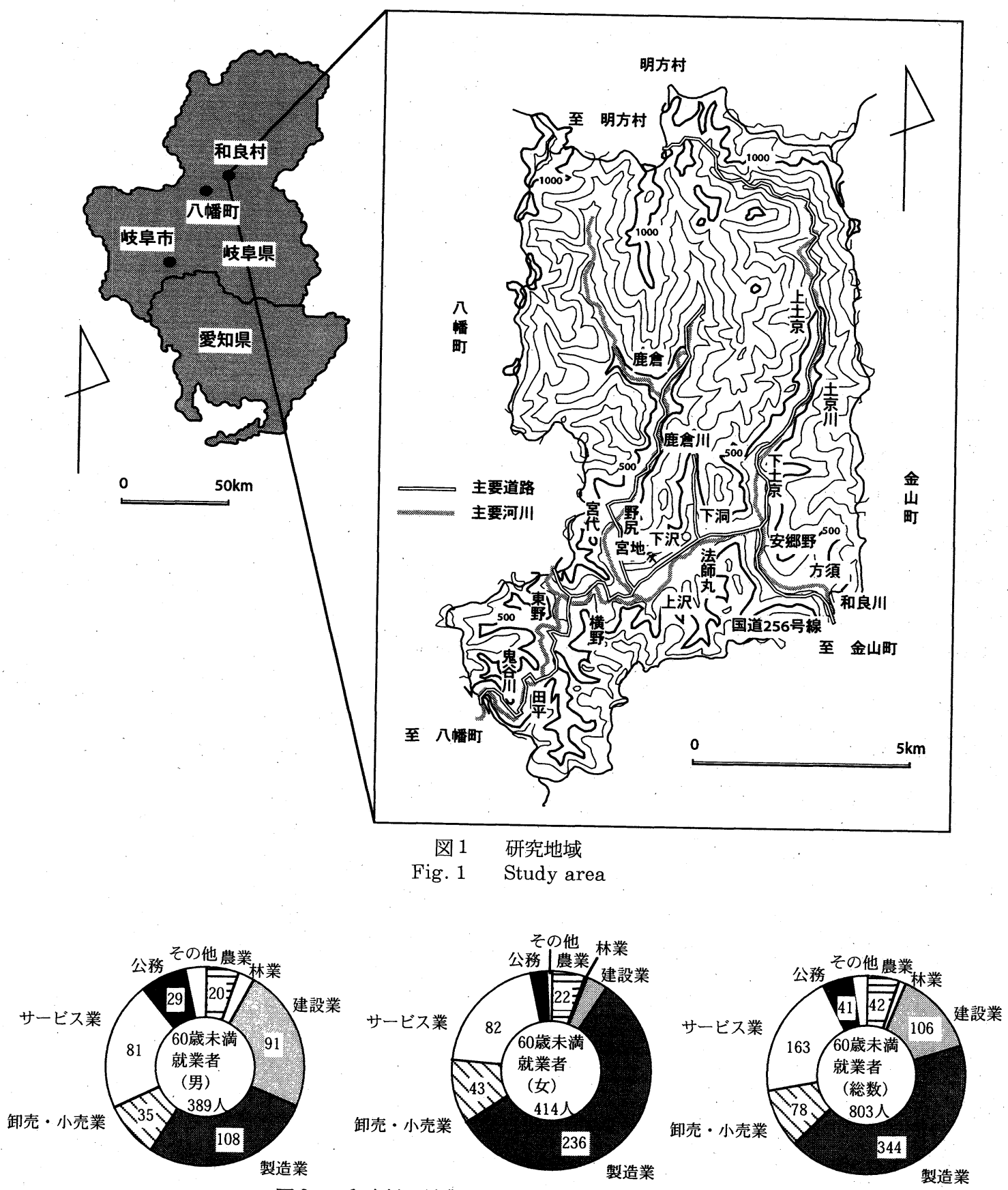

図 2 和良村で従業する 60 歳未満の産業別就業者数 (国勢調查 (1990) による).

Fig. 2 Number of employees under 60 years of age by industry 
表 1 調查対象事業所の分類

Table 1 Types of establishment surveyed in this study

\begin{tabular}{l|l}
\hline \multicolumn{1}{c|}{ 事業所の区分 } & \multicolumn{1}{c}{ 調查対象事業所 } \\
\hline (1) 転勤がある公的・半公的事業所 & 郵便局, 小・中・高等学校 (教員) \\
(2) 転勤のない公的・半公的事業所 & $\begin{array}{l}\text { 村職員（特別会計分の病院を含む), } \\
\text { 農協, 森林組合, 商工会 }\end{array}$ \\
(3) 従業員規模 10 名以上の民間事業所 & $\begin{array}{l}\text { 従業者規模 } 10 \text { 名以上小村内民間事業所 } \\
\text { (4) 自営業事業所 }\end{array}$ \\
& 商工会青年部部員 \\
& ((3)と重複する場合は(3)に算入) \\
\hline
\end{tabular}

員で女子に偏っているのに対して，公務や建設業の 就業者は男子が中心であり，財政支出による雇用創 出の効果は男子において顕著である.

以上で述べたように和良村は（1）都市からの隔 絶性，（2）建設業や公共サービス雇用への強い依 存, という 2 点において奥地山村の典型的な特徵を 示しているといえる，和良村での現地調査では，限 定された村外就労機会を前提に，村内事業所の動向 および労働力編成と青年男子従業者の就業過程とを 明らかにするために，村内各事業所に対して事業内 容・労働力編成・労働条件などについてのヒアリン グ調査を実施し，併せて各事業所の 40 歳未満の男 子常雇職員を対象に居住地移動歴などについてアン ケート調査を実施した ${ }^{4)}$ 。さらに，和良村へのU夕 ーン者については帰村意志の有無5についても調查 した. 40 歳を調查対象の区切りとしたのは, 和良 村ではおおよそこの年齢よりも下の世代において高 校皆進学化が定着していることによる.

調査を実施するにあたり，以下のように村内事業 所を分類した。

まず村内事業所は経営主体の面から公的・半公的 事業所と民間事業所とに二分される.このうち公 的・半公的事業所は, 学校・郵便局など一定の周期 で転勤がある事業所と，役場・森林組合などの転勤 のない事業所とを分ける必要がある．これは前者の 事業所の場合, 職員の多くが村外からの通勤あるい は一時的居住者で，村内定住と直接の関係を持たな いためである．一方村内の民間事業所の場合，こう
した転勤のある事業所はほとんどない。これらは経 営形態, 就業構造の面から, 主に事業主と家族従業 者で構成される自営業ないしはそれに準じる小規模 な事業所と, 一定以上の従業員規模を持ち, 雇用者 が中心となる事業所とを別扱いにする必要がある.

以上，本研究では村内事業所を（1）転勤がある 公的・半公的事業所，（2）転勤のない公的・半公 的事業所, (3) 従業員規模 10 名以上の民間事業所, (4) 自営業事業所の四つに分類した ${ }^{6)}$. 本調査で 調査対象とした事業所は表 1 の通りである。なお （4）には従業員 10 名末満の事業所も含まれるが, 規模の面から自営業として扱った7). また（1）の 転勤がある公的・半公的事業所については従業員の 大半が村内常住者ではないため, アンケート調查の 対象からは除いた。

\section{III 村内事業所の雇用形態と青年男子の就業過程}

1. 調查対象事業所の雇用形態

（1）転勤のある公的・半公的事業所

和良村内で定期異動のある公的・半公的事業所は 小・中・高等学校 (事務職員を除く) と郵便局であ る. 小・中・高等学校の教員の場合, その半分は八 幡町を中心とする村外からの通勤者で，もう半分は 村内の教員住宅に暮らす一時的居住者となっており， 村内常住の教員は 2 人だけである. 郵便局の場合は 内勤者と外勤者で異動の形態が異なりり，外勤者の場 合は本人が希望を出さない限りまず異動はない，和 良郵便局の場合, 内勤は 5 名中 1 人, 外勤は 5 名中 
表 2 転勤のある公的・半公的事業所の年齢別従業員数

Table 2 Number of employees of public or semipublic establishments with regular workplace relocation by age-group

\begin{tabular}{l|r|rrrc}
\hline \multicolumn{1}{c|}{ 事業所 } & 常雇規模 & 20 歳代 & 30 歳代 & 40 歳代 & 50 歳代 \\
\hline 小・中・高等学校教員 & $33(12)$ & $7(4)$ & $7(3)$ & $15(3)$ & $4(2)$ \\
和良郵便局 & $10(0)$ & $1(0)$ & $2(0)$ & $6(0)$ & $1(0)$ \\
\hline
\end{tabular}

(聞取り調查により作成).

表 3 転勤のない公的・半公的事業所の年齢別従業員数

Table 3 Number of employees of public or semipublic establishments with no regular workplace relocation by age-group

\begin{tabular}{|c|c|c|c|c|c|c|c|c|c|c|c|}
\hline 事業所 & 常雇規模 & ～24 歳 & ２9歳 & $\sim 34$ 歳 & $\sim 39$ 歳 & $\sim 44$ 歳 & $\sim 49$ 歳 & ～54 歳 & ～59 歳 & ～64 歳 & 65 歳 \\
\hline 村一般会計職員 & $59(20)$ & $7(2)$ & $5(1)$ & $8(3)$ & $6(2)$ & $17(10)$ & $12(1)$ & $3(1)$ & $0(0)$ & $1(0)$ & $0(0)$ \\
\hline 和良病院 & $43(30)$ & $1(0)$ & $1(1)$ & $6(5)$ & $9(3)$ & $7(7)$ & $12(11)$ & $5(2)$ & $1(1)$ & $1(0)$ & $0(0)$ \\
\hline 郡上農協和良支店 & $13(5)$ & $2(0)$ & $2(1)$ & $2(1)$ & $1(0)$ & $4(2)$ & $2(1)$ & $0(0)$ & $0(0)$ & $0(0)$ & $0(0)$ \\
\hline
\end{tabular}

(聞取り調查により作成).

4 人が村内常住者となっている．転勤のある公的・ 半公的事業所の場合, 職員の年齢構成は組織全体で 平準化されるため, 村内の他の事業所に比べると青 年就業者の割合は高い（表 2 ).

（2）転勤のない公的・半公的事業所

役場職員や病院の事務職などで構成される一般行 政職員は, 福祉行政の拡充, 公共投資の拡大などに 伴う事務量の増大から，課制の導入などの組織改編 が行われた 1960 年代後半から 1970 年代前半に大量 の職員採用を行い, 現在の 40 歳代に団塊の世代が 形成されている（表 3 )。これに対し，1970 年代後 半から 1980 年代前半は行革路線の下で定員が抑制 されて職員の採用数は少なく, 1975〜1984 年の 10 年間のうちに一般行政職採用が 0 人の年が 4 年もあ り, 一転して 30 歳代の職員数は少ない. 1990 年以 降は毎年 3 名前後の職員が新規に採用されている. 一方, 病院の現業職は, 1980 年代以降, 経営状況 の悪化から, 医師など必要最小限の職員更新を除い て募集を行っていない.

定期異動のない公的・半公的事業所は, 内勤であ るという点を含め, 賃金面・福利厚生面などの労働
条件で村内事業所の中では最も条件に恵まれてい る ${ }^{8)}$. 福利厚生制度も整っているので, 女子も含め て転職する事例はまれであり, 職員の自主退職に伴 って新規雇用が生まれることは少ない。医師や各種 技師など病院の現業職は資格取得過程を経る必要が あり, 僻遠地に位置するため職員の確保が難しい9). 農協の場合は広域合併されたため, 郡上農協全体 で採用業務を行っている10). 合併後, 公募による採 用試験が実施されるようになり, それ以降, 職員構 成の面でも労働条件の面でも役場との類似性は高い. 森林組合は理事長 1 人, 事務職員 1 人, 現場作業員 3 人の 5 人構成で, 経営上の問題から 1982 年を最 後に職員は採用していない. 現場作業員の場合, 仕 事の内容は建設業や製造業の労務職に近い上, 労働 面での負荷は村内の労務職の中でも最も大きい部類 に属する.

(3) 従業者規模 10 名以上の民間事業所

調査対象となった従業者規模 10 名以上の村内民 間事業所の内訳は建設業 5 , 製造業 5 , 養鶏場 1 の 11 事業所であり；うち村外資本によるものが 4 事 業所（製造業 3 , 養鶏場 1 ) ある.このカテゴリー 
表 4 従業員規模 10 名以上の民間事業所の年齢別従業員数

Table 4 Number of employees of establishments with 10 or more employees by age-group

\begin{tabular}{|c|c|c|c|c|c|c|c|c|c|c|c|c|c|}
\hline 事業所名 & 産業区分 & 業種 & 常雇職員数 & $\sim 24$ & $\sim 29$ & $\sim 34$ 歳 & $\sim 39$ 歳 & ４4 歳 & & ～54 歳 & ～59 歳 & ～64 歳 & 65 歳〜 \\
\hline 清水建設(有) & & 土木業 & $22(2)$ & $1(0)$ & $1(1)$ & $3(1)$ & $3(0)$ & $3(0)$ & $1(0)$ & $1(0)$ & $2(0)$ & $3(0)$ & $4(0)$ \\
\hline & & & $18(2)$ & & & & & $1(0)$ & $3(2)$ & & & & $5(0)$ \\
\hline & & & $13(2)$ & & & & $1(1)$ & $1(1)$ & $0(0)$ & & & $4(0)$ & $4(0)$ \\
\hline 古川土木(株) & & & $14(3)$ & ( 0$)$ & $0(0)$ & $0(0)$ & & $1(0)$ & $3(1)$ & & & $2(0)$ & $7(1)$ \\
\hline (有)澤建設 & 建設業 & & $11(1)$ & $0(0)$ & $0(0)$ & $0(0)$ & & $1(0)$ & $1(1)$ & & & & \\
\hline $\begin{array}{l}\text { (森)松日 } \\
\text { 工業臬 }\end{array}$ & 製造業 & $\begin{array}{l}\text { 電機機器 } \\
\text { 工場 }\end{array}$ & $117(103)$ & $2(0)$ & $0(0)$ & & & $12(10)$ & $23(23)$ & & $25(23)$ & $20(17)$ & $10(9)$ \\
\hline 伊藤才 & 製造業 & & $17(6)$ & $0(0)$ & $0(0)$ & & & $2(1)$ & $1(0)$ & & & $2(1)$ & $6(1)$ \\
\hline 郡上協和(有) & & & $10(3)$ & $0(0)$ & $0(0)$ & $0(0)$ & & $0(0)$ & $2(2)$ & $1(0)$ & $0(0)$ & $4(1)$ & $2(0)$ \\
\hline $\begin{array}{l}\text { 夕ッッ } \\
\text { ズ(森) }\end{array}$ & & & $16(8)$ & $0(0)$ & & & & $0(0)$ & $0(0)$ & & & & $5(3)$ \\
\hline $\begin{array}{l}\text { ヤナイイン } \\
\text { ダストリィ(侑) }\end{array}$ & 製造業 & 鉄工所 & $13(1)$ & $0(0)$ & $0(0)$ & $0(0)$ & $2(0)$ & $1(1)$ & $1(0)$ & $1(0)$ & $3(0)$ & $2(0)$ & $3(0)$ \\
\hline 伡沢木工所 & 製造業 & 木工所 & $12(6)$ & $0(0)$ & $0(0)$ & $1(1)$ & $1(0)$ & $2(1)$ & $1(1)$ & $2(1)$ & $1(1)$ & $2(1)$ & $2(0)$ \\
\hline
\end{tabular}

（）内は女子.

(聞取り調查により作成).

に該当する事業所は，業種と資本形態から，（a ） 建設業事業所，（b）村外資本の製造業事業所（養 鷄場を含む)，（c）村内資本の製造業事業所の三つ に分けられる.

\section{a．建設業事業所}

調查対象となった五つの建設業事業所のうち四つ が土木事業所であり，これらの職員構成は互いに類 似している (表 4$)$ ，職員の大部分は，経営者も含 め，いわゆる土工として外仕事を担当する男子現場 労務職員である.このほかには経営者の夫人など家 族労働力を中心とした数名の女子事務職員がおり, 例外的に取引上の関係から先代経営者がオーナ一的 に名を連ねていたり，男子営業職員を置いていたり している事業所もある.

給与体系は日給・月給制が一般的で, 青年労働者 など各社数名の従業員が月給制となっている11). 月 給制の場合，初任給は 18〜20万円で, 村内事業所 の中では最も高い．現在，どの事業所でも現場労働 者の高齢化とそれに伴う労㗢力不足が深刻な問題と なっているが, 青年労働力の確保状況には事業所間 にかなりの格差がある. しかし既存労働力の高齢化 に見合った労㗢力更新のできている事業所はなく，
年々労働力不足が樑刻化している．また公共事業を 受注するには, その条件の一つとして技術者の確保 が重要であるが, 各種の資格の取得は労働力の市場 価值を高めることにもつながるため，取得を転機に， より労働条件の良い事業所へ移籍してしまうことも 少なくない:これら技術者の確保は各事業所にとっ て死活問題であり, 社内での技術者養成能力の低い 事業所を中心に, 職業安定所や村外への個人的な勧 誘を通じて技術者の確保を図っている. 測量士や土 木施行管理技師などの資格保有者の場合, 資格や経 験にもよるが，初任給は 25〜35 万円に達する.

土木事業所は，すべてが法人であり，10 名以上 の従業員規模を持っているなど, 村内の地元資本の 事業所の中では最も有力な事業所である. そのため, 4 事業所中, 子供が幼い 1 事業所以外は, 後継者な いしはその候補が確保されている。

建築業で, 従業員規模 10 名以上の事業所は木工 建築業者の 1 事業所だけである.この業者は名古屋 で大工として働いていた仲間数名で設立され, 事業 実績に基づく高い信用から, 郡内にとどまらず愛知 県北部まで幅広く仕事を受注している. 土木事業所 に比べて職人を必要とするので, 労働力の高齢化問 
題は一層深刻であり, 若い人を入れてもなかなか定 着してくれないという悩みがある12).

\section{b．村外資本の製造業事業所}

村外資本の工場の場合, 工場長が他工場から赴任 してきた養鶏場を除いて, 工場長以下すべての従業 員が地元の住民である. 労働力確保から工場管理ま ではすべてが工場に一任されているが, 生産指令な どの管理・営業部門は本社からの指令に従う．新し い機械の導入や正規職員の採用時など必要に応じて 本社職員が派遣されるが，常駐しているケースはな い. 管理・営業部門を持たないため, 工場長のほか 少数の事務職員を除くとすべてが現場労務職員であ り，工作機械のオペレーターなどを除くとほとんど が高齢労働者や女子のパートタイム労働者で占めら れる.

村唯一の大規模工場である（株）松田電機工業所 はもともとは八幡町入間地区にあった工場である. 事業の拡大に伴って工場の新築移転を計画し，八幡 町内に用地を求めたが適当な物件が見当たらなかっ たときに，工場の誘致を目指していた和良村が複数 の地権者から工場用地をまとめて斡旋したことによ って，1984 年に立地した.（株）松田電機工業所は 自動車のワイパーなどのスイッチを製造しており, 手作業でなければできない工程を多く抱えた典型的 な労働力集約型の工場で, 職員の 9 割が中高年の女 子労働力である. 規模が大きいため労働力は広く近 隣町村からも充当され， 3 系統の送迎バスが運行さ れている. 100 名以上の従業者を抱えるこの工場で は男子職員と女子職員は明瞭に区別され13)，女子職 員が一部の事務職員を除いてすべて熟練度を必要と しない現場労務職員となっているのに対し, 男子職 員は全員, 工作機械のオペレーターあるいは各工程 の管理者としての班長・係長となっている14)，その ため男子に関しては, 従業員規模から見れば少数で あるが, 青年雇用が見られる. しかし, 初任給は 12 16 万円と土木事業所に比べると低く, 地元青
年の減少によって男子労働力の不足は年々深刻化し, 男子労働力を要する工程の維持が難しくなっている.

伊藤木管（株）など他の事業所では, 必ずしもす べての事業所が採用活動を行っているわけではない が，いくつかの事業所の職業安定所への募集を見る と, 給与はおおよそ（株）松田電機工業所と同様の 水準である. しかし実際には職業安定所経由で雇用 が決められることはまれで, 工場長之周辺住民との 直接交渉や, 親会社を通じた外国人労働力の供給な ぞの形で労働力が編成されている. 労働力は（株） 松田電機工業所と比べ, 著しく高齢化が進んでいる.

c. 村内資本の製造業事業所

村内資本によって操業中の工場のほとんどは従業 員規模 10 名に満たない零細な事業所である. 調査 対象となったのは木工業の（有）沢木工所と鉄工業 のヤナイインダストリィ（有）の 2 事業所のみで, 両事業所とも現在の事業を始めたのは 1960 年代後 半から 1970 年代前半にかけてである. 共に刃物や タイヤのホイールを対象とした研磨業からの転業で あり, 経営者が技術面・経営面・営業面のすべてを 取り仕切っている. 労働力編成はほぼ伊藤木管 （株）などの村外資本の製造業事業所に準じたもの となっている.

\section{(4) 自営業事業所}

商工会青年部の部員は, 事業所規模の小さい建築 業を中心に建設業に属する部員が約半分を占め, サ ービス業や小売業に従事する部員は少ない，商工会 青年部のメンバーは全員が地元出身者であり, 外部 からの参入はまったくない，近年は親が家業を継ぐ ことを子に強要することは少なくなり，事業所経営 のしっかりしている土木業を除くと家業を継ぐこと は少ない，その一方で新規起業が見られる業種は建 設関連に限られている．ただし中には酒屋経営から スナック営業への転業や農地コンサルタントの新規 創業によって生存戦略を図っている事例も見られる. 
表 5 アンケート調査の概要

Table 5 Summary of the questionnaire survey

\begin{tabular}{|c|c|c|c|c|c|}
\hline & $\begin{array}{c}\text { 従業地による就業者数 } \\
\text { (1990) (A) }\end{array}$ & 調査対象者数（B） & 回収数 (C) & $\begin{array}{l}\mathrm{C} / \mathrm{B} \\
(\%)\end{array}$ & $\begin{array}{l}\text { C/A } \\
(\%)\end{array}$ \\
\hline 農業 & 5 & 3 & 3 & 100.0 & 60.0 \\
\hline 林業 & 1 & 0 & 0 & - & 0.0 \\
\hline 製造業 & 28 & 12 & 10 & 83.3 & 35.7 \\
\hline 建設業 & 26 & 20 & 18 & 90.0 & 69.2 \\
\hline 運輸・通信業 & 3 & 0 & 0 & - & 0.0 \\
\hline 卸売・小壳業 & 12 & 5 & 4 & 80.0 & 33.3 \\
\hline 金融保険業 & 2 & 0 & 0 & - & 0.0 \\
\hline サービス業 & 38 & 15 & 13 & 86.7 & 34.2 \\
\hline 公務 & 13 & 18 & 12 & 66.7 & 92.3 \\
\hline 計 & 128 & 73 & 60 & 82.2 & 46.9 \\
\hline
\end{tabular}

(アンケート調査および国勢調査 (1990) により作成).

\section{2．青年男子の就業過程}

本研究での調査対象者数と 1990 年国勢調査の従 業地における 40 歳未満の産業別男子就業者数との 関係は表 5 の通りであり, 国勢調査の就業者数に対 する調查対象者数の割合（B／A）は $57 \%$ であ る15).これに対してアンケートの回収数は 60 票で 回収率（C／B）は 82\%，国勢調査の就業者数に 対する割合（C／A）は 47\%である. 1995 年の国 勢調査が集計期にあるために 1990 年の国勢調查結 果を用いたが，過疎地域である和良村において対象 となる従業者数が増えているとは考え難いので, 実 質的な回収率はこの数字を上回ると思われる，以下， 前節の分類に従って検討する.

（1）転勤のない公的・半公的事業所

転勤のない公的・半公的事業所のうち, 一般行政 職員（役場および病院の事務職）は公募による採用 試験に合格する必要があるため, 新規学卒時の採用 が多い. 岐阜県では小規模町村の職員採用事務の軽 減を目的に統一採用試験を実施しており, 和良村も それまでの村自身の手による簡単な面接を通じた採 用から，十数年前にこの試験制度に切り替えた. 統 一試験の利用に伴って採用が大卒を対象とした 1 種 と高卒を対象とした 2 種とに分けられ，学歴が給与 などに反映されるようになったため，かっては村内
にある郡上高校和良分校から役場就職という採用経 路が大半を占めていたのに対して, 次第に短大・大 卒等の高等教育修了者の新卒採用やU ターン採用な ど, 多様な採用経路が見られるようになった。 ただ し高卒後に他出して就職し，その後に役場に就職し た事例は 1 例にすぎず（図 3 16），ID01），この 1 例 も高校卒業後の就職先を 1 年もしないうちに退職し; 専門学校へ入り直した事例である.すなわち中卒・ 高卒者の場合, 採用試験が参入障壁となり, 新規学 卒時以外での一般行政職への就職は, アンケート結 果を見る限り非常に少数となっている.

農協についても, 広域合併後は郡上農協全体によ る一括採用になり, 役場同様に公募による採用試験 が実施されるようになったため，農協の採用経路は ほぼ村の一般行政職員に準じたものになっている。

一般行政職員之農協職員の 17 事例のうち, 新規学 卒就職は 12 例にのぼり, 25 歳以上で就職した事例 は 3 例にすぎない.

病院の現業職は, 前記した村の奨学金制度によっ て医師以外の大半は村出身者によって充当され，そ の多くは専門教育を受けた新規学卒者であった：医 師のみは派遣医師として一時的居住者となっている (図 3, ID17).

森林組合の場合, アンケートの調査対象となった 


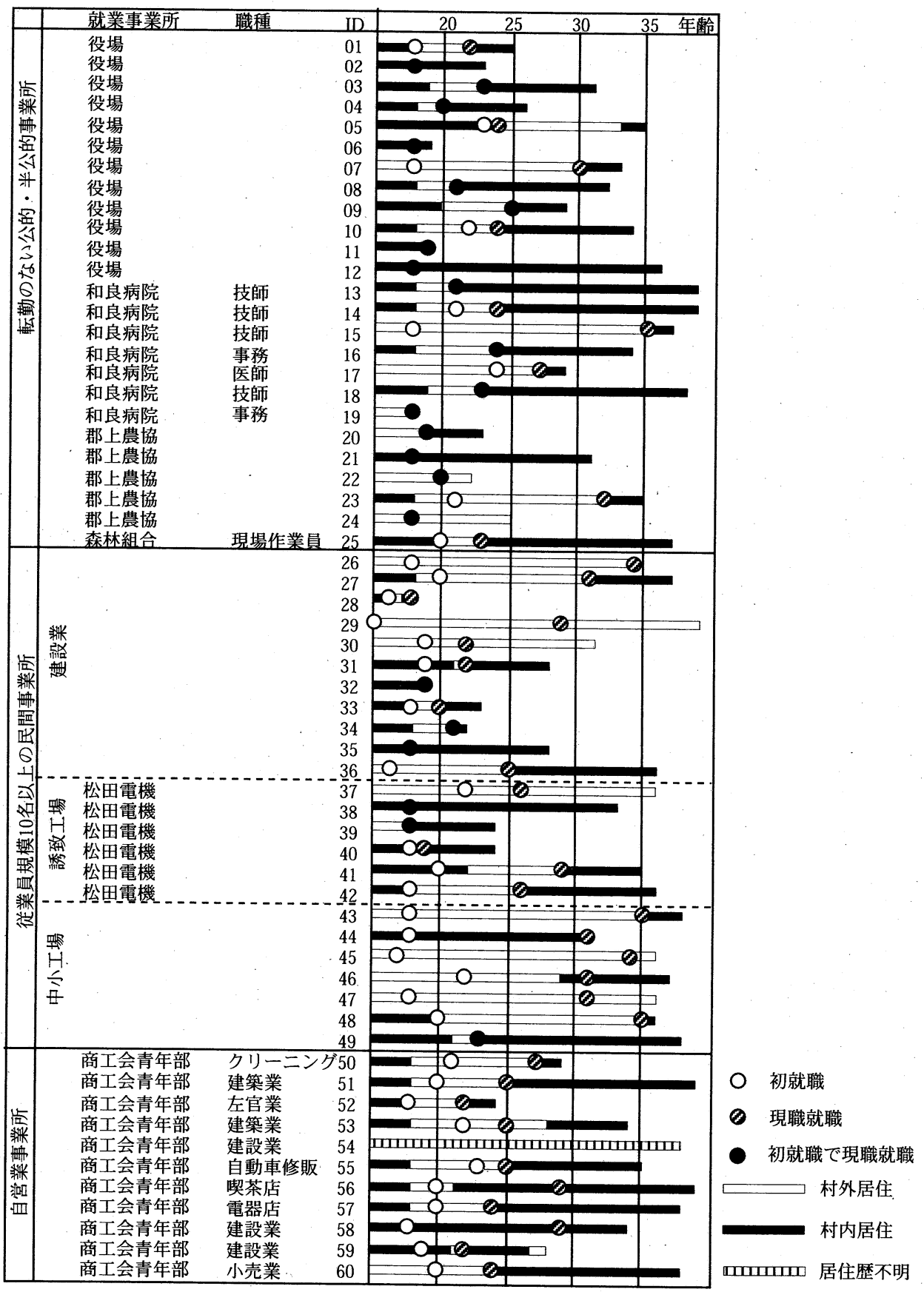

図 3 従業員の移動および就業歴

個人の特定を避けるため一部の就業事業所名を燰匿した.

(アンケート調查により作成).

Fig. 3 Migration and occupational career of employees 


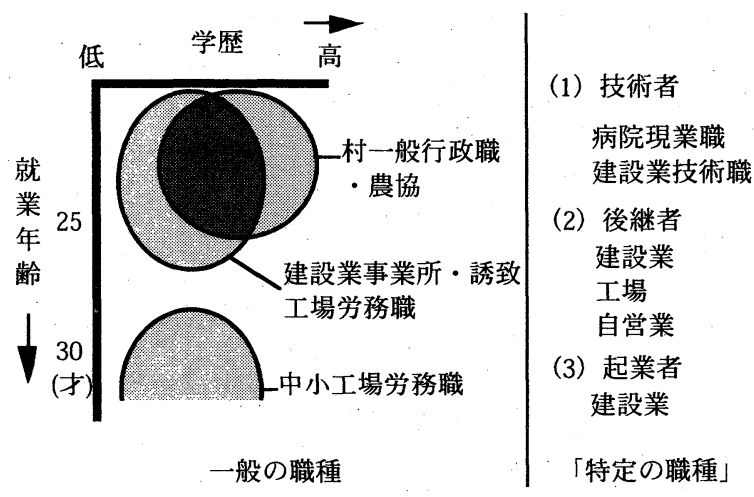

図 4 和良村における青年男子の職業構造

Fig. 4 Structure of occupations in Wara village

1 事例は現場作業員であり，一般の労務職就職に準 じ，高校卒業後，自衛隊17)を経由して森林組合に就 職している（図 3, ID25）.

（2）従業員規模 10 名以上の民間事業所

a. 建設業事業所

アンケートの回答は 11 事例あり, 10 事例が土木 業者の職員である. うち 3 事例は新規学卒者であり, このほかに自衛隊を経由して就職した事例が 1 事例 ある.これらのうち 1 事例だけは高卒後に名古屋の 工業専門学校を経ており, 専門の営業職員として勤 務している(図 3, ID34). 現職就業年齢は若く, 7 事例は 25 歳以下で就職している. 一方, 技術者の 場合は労働力不足が深刻であるため, 現場経験のあ る左官や測量関係の技術者が 30 歳前後の年齢で就 業している(図 3, ID26, 27).

建築業の 1 事例は大工であり, 中学卒業後, 岐阜 市の職業高等訓練校に 1 年通った後に愛知県の建築 会社に就職し，25 歳の時に帰村, 就職している (図 3, ID36).

b. 村外資本による製造業事業所

アンケート回答の 10 事例のうち，6 事例が松田 電機の職員である. 松田電機の場合, 事業所の組織 が大きい上に男子職員には相応の職場が与えられる ために, 5 事例は 26 歳以下の年齢で就職している.
そのほかでは養䳕場のタッキフーズ（株）が 3 事例， コンクリート製造業の郡上協和（株）が 1 事例であ る. 養鶏場の 3 事例のうち，1 事例は場長であり, 本社採用組として和良村の養鶏場に赴任してきた事 例である. 残りの 2 事例は建設業者と村内の工場か らの転職で, 現職就業年齢は 30 歳を過ぎてからで ある. 郡上協和（株）の 1 事例は結婚に伴って妻方 の実家に移ってきた事例で, 以前は大手のゼネコン に勤めていて重機のオペレーターとしての技術を持 っていたため，時期を同じくして創業した郡上協和 の工場長に請われる形で 31 歳で就職している.

c．村内資本による製造業事業所

村内資本による製造業事業所は対象事業所が 2 事 業所しかなく，アンケート対象職員はわずかに 3 名 であった. 1 事例は木工所の跡取の弟で塗装部門を 管理している（図 3, ID49)。彼はデザインの専門 学校を卒業した後, 兄と共に木工所の面倒を見るよ うになった. 他の 2 事例は鉄工所の職員であり， 1 事例は経営者の従兄弟で自動車修理工場から転職し， もう 1 事例は前の勤務工場での夜勤を嫌って転職し ており，共に現職に就業したのは 30 歳を過ぎてか らである.

ただし一般的な傾向として，村内資本の工場は建 設業の事業所や村外資本の工場に比べて敬遠される 傾向が強く，アンケート中, 新規学卒後に村内資本 の工場に就職した後, 2 年以内に転職して村外へ流 出した事例が 3 事例（縫製工場 2 事例, 鉄工所 1 事 例）あった。こうした事例の多くは，就職先の決ま っていない地元の新規学卒者に血縁者や地縁者が話 を持ちかけて就職が決まったものの，仕事への不満 が募り，関係者への義理から $1 \sim 2$ 年勤務した後に 退職していった事例であるといわれる18).

(3) 自営業事業所

自営業の場合, 当初から新規起業あるいは家業を 継ぐ意志を持ち，建設業事業所の大工の事例と同様 に専門教育を受け，同業者の下での技術習得の過程 
を経て帰村した事例と，とくに帰村する意志のない まま村外で就職してからUターンしてきた事例とに 二分される．前者の場合は電気店, 自動車修理販売 店の事例があり, 後者の場合は建設業が多い.

いずれの場合も 20 歳代半ばから後半に州村・現 職就業する場合が多く, 帰村・現職就業年齢が確認 できた 10 事例のうち 8 事例は 24 29 歳の間での帰 村・現職就業となっている．学卒後すぐに現在の職 業についた事例は皆無であり, 1 事例（図 3, ID 58）以外はすべて何らかの形で他出経験がある.

\section{3. 青年男子の就業過程から見た職業構造}

以上の分析によって青年男子の就業過程の面から 村内の職業構造をまとめると図 4 のようになる。 ま ず村内の職業は, 資格や経験を必要とする職業（技 術者）や後継者・起業者などの「特定の職種」と， それ以外の一般の職種とに分類できる。一般の職種 の場合, 新規学卒者や 20 歳代前半での就業が見ら れるのは, 一般行政職・農協のグループと建設業・ 誘致工場労務職のグループの 2 種類である. 一般行 政職・農協への就業者は公募による採用試験の存在 によって新規学卒時での就業が多く, なおかつ一般 行政職員の場合, 大卒での採用経路があるため高学 歴者が比較的多いのが特徵である. 建設業事業所の 場合は, 職種上ほとんどが高卒者であるが, 村内の 労務職の中では, 仕事の負荷が大きいものの, 最も 給与条件が良いため, 就業年齢はほとんどが 20 歳 代前半以下となっている.これに対して誘致工場の 労務職の給与水準は決して高くはないが, 仕事内容 や福利厚生面の充実, 会社の安定性などから選好さ れていると思われる.

これに対し, 労働条件で劣る中小工場への労務職 就業者は, 後継者の 1 人を除いてすべて 30 歳を超 えてからの就業となっており, 建設業事業所および 誘致工場の労務職とは明瞭な就業年齢の差が見られ る.
特定の職種においては年齢や学歴にかかわらず参 入が可能であり, 主に（1）技術者，（2）後継者, （3）起業者の 3 形態が存在する. 和良村の場合, 技術者には建設業技術者やかつての病院現業職が挙 げられる．これらの技術者は事業所の運営上必要不 可欠な存在であるにもかかわらず労働力不足が生じ ており, 売り手市場の下で就業することが可能とな うている. 建設業技術者の場合は経験者として村外 常住者やUターン者の 30 歳代での就業が見られ, 病院現業職の場合は奨学金制度を設けることで村内 出身者からの労働力の確保を図った. 後継者の場合 は年齢自体に制約されることはないが, 和良村の事 例では, 高卒後に専門教育を受け, 同業他社で一定 期間の職業経験を経た後に後継者として就業するケ ースと, モラトリアム的な村外就職を経てUターン してきたケースとに分かれ，年齢的には 20 歳代半 ばから後半が多い. 和良村の場合, 起業者のほとん どは建設関係の業種であるが, 跡取同様に 20 歳代 半ばから後半にかけての時期に起業しているケース が多い.

30 歳を過ぎてからの就業者が中心となっている 村内の中小工場への就業者は, 後継者のほかには 1 名だけが村内出身者で, あとは村外出身者である. このことを考えると, 少なくとも村内事業所へ就業 する場合の村内出身者の帰村は, おおよそ 30 歳が 上限となっていることがうかがえる. 実際にU夕ー ン経験のあるインフォーマントから「鹵村するなら 30 歳までにと考えていた」という意見が出されて いる. しかし労務職に関していえば, 村内各事業所 の労働力編成を考えると, 30 歳を超えたからとい って就業条件が急変するとは考えがたい. むしろ近 隣関係の濃密な農村地域社会への融合過程, 結婚・ 出産などによるモビリティの低下, 帰村時の所得減 少額の増大などさまざまな要因を併せて考えたとき に, 30 歳という区切りの年齢が䚻村の上限として 村内出身者の中で漠然と共有されている，と考える 
のが妥当であろう.

第正章第 2 節で村内民間事業所の労働力不足の問 題を指摘したが, 現状では事実上, 公的・半公的事 業所と建設業事業所の一部のみが新規学卒者を就職 の対象としている. 残りの事業所は，募集をしても ほとんど効果の上がらない新卒労働市場から撤退し て, 長男などのUターン者や結婚して妻方の実家に 同居している者などの既就業者に働きかけて労働力 を集めている. しかし都市部の中小工場ですら労働 力不足に悩む昨今, 十分な労働力を確保することは 困難である. 給与水準をはじめとした労働条件が大 きく異なる以上，今後も和良村の青年男子が公的・ 半公的事業所や建設業事業所を指向する傾向は变ら ないと思われ, 地域雇用の創出ひいては人口維持の ために財政支出が果たす役割は，今後ますます大き なものになろう。

\section{IV まと.め}

本研究では岐阜県郡上郡和良村を事例に, 村内各 事業所の労働力編成および青年男子従業者の就業過 程に関して調査し，村内の職業構造を分析した．そ の結果, (1) 和良村内の職業は就業年齢之従業員 の学歴の点から(1)農協職員之村一般行政職員, (2)建 設業事業所と誘致工場の労務職, (3)中小工場労務職 の三つのグループに分類されるとともに，これら 2 点の制約を受けない職種が存在し, 跡取や技術者, 起業家によって構成される,（2）農協職員之一般 行政職員のグループは高学歴取得者や新規学卒者の 勤め先として特徵的な位置を占めており, 唯一高齢 従業者の引退に伴い労働力の更新が実現されている, という 2 点が明らかになった.

奥地山村や離島で適正規模のコミュニティを維持 していくためには依然として雇用の問題が重要な位 置を占めているが，その一方でこうした地域におけ る公共サービス雇用は地方分権化が本格化していく 中で非効率な行政システムとして批判され, 建設業
も環境保護の風潮が強まる中で自然破壊の担い手と して非難されている. 奥地山村や離島には, むらお こし事業などによる内発的な発展の可能性が低い所 が多く, もし今後も公共性の面から地域社会・人口 を維持していく必要があるとすれば, どのような形 での財政支出と雇用創出が適当であるのかについて, 本研究で示したような現状を踏まえて再検討される べきであろう.

本稿の作成にあたっては現地調查では和良村役場総務 課の川尻氏, 和良村商工会指導員の渡辺氏をはじめ関係 者の皆様に大変にお世話になりました. また, 日頃御指 導を受けている東京大学教養学部人文地理学教室の諸先 生方・院生の皆様から有益な御指導・御批判をいただき ました.ここに深謝の意を表します. 本稿の内容は 1996 年度に東京大学総合文化研究科に提出した修士論 文の内容をもとにしており，その骨子は 1997 年 3 月の 日本地理学会春季学術大会および同年 4 月の経済地理学 会例会（修士論文発表大会）で発表した.

(投稿 1997 年 7 月 30 日) （受理 1998 年 2 月 7 日）

\section{注}

1） 1970 年に制定された過疎地域対策緊急措置法は 10 年 の時限立法であり, 1980 年には新たに過疎地域振興特 別措置法が制定された. 同様の経緯で 1990 年には過疎 地域活性化特別措置法が制定されている，過疎法という 表現はこの 3 法を統一的に扱うときの表現として用いら れている.

2)「奥地山村」という用語について, 既存研究では宮口 (1978）が「都市およびその周辺の生産力の高い地域へ 日常の行動がおよび得ない」山間地域の意味で用いてお り, 安食 (1993) もこの定義を使っている. 本稿では, 宮口（1978）の定義から, より就業機会の面を重視して, 「地理的条件から外来型産業の立地が困難で, かつ都市 就業機会へのアクセスが困難な」山村という意味で用い る.

3 )これは 1991 年の事業所統計における和良村のサービ 業事業所従業者 175 名のうち, 108 名が国・地方公共 団体の事業所従業者であったことを踏まえて推計したも のである.

4 ）アンケート調查は対象者の同定作業の後に, 事業主に 依頼する形で対象者に配布し，回収時に回答者立会いの 下で内容をチェックした．これは理論的整合性を持たな 
い回答や筆者が疑問に思った事項について確認を求める ためである. 回答者が不在の場合には, 関係者への聞取 りなどを補足的に実施した。 また本調査は（1）仕事内 容を正確に把握する，（2）回収率が低くくなりがちな 青年層から一定水準の回収率を確保する, という目的の ため事業所経由で調査を実施した。

5 ) アンケート調查の中で一度村を出た後に村に戻ってき た, いわゆるUターンの回答者を対象に, 他出当初から 帰村の意志があったかどうかの質問を設けている. 本稿 ではこの質問への回答結果をもって「帰村意志あり」 「鹵村意志なし」という表現をしている.

6) 対象となる民間事業所の同定においては, 和良村商工 会が 1996 年 2 月に実施した従業員数の調査を元にその 後の雇用状況を考慮して，同商工会の指導員から指示を いただいた. なお農協は 1973 年に広域合併したが, 職 場は居住地を強く考慮したものとなっており, 和良支店 でも従業員 13 名中 10 名が村内常住者となるので, 転勤 のない公的・半公的事業所に含めている.

7 ) 従業員規模 9 名以下の事業所の 40 歳未満の常雇職員 について, 商工会において確認されたのは 7 名である. 内訳は建設業事業所（建築業，ガス・管工事，電気工 事) が 6 名, サービス業事業所（自動車修理販売）が 1 名であった. また商工会青年部の会員条件である「村内 で商工業を営むものまたはその子弟」という条件を満た しているにもかかわらず入会していない人の人数は, 商 工会で把握している限りで 5 名いる.このうち, 子が親 の家業を継ぐ意志がない 1 名を除くと，独立・開業した ばかりでまだ入会する余裕がない, というのが大半の理 由となっており, 将来的には入会の意志を持っている.

8 ）和良村自体の給与体系は分からないが, 地方公務員給 与制度研究会編『地方公務員給与の実態』によれば, 和 良村の一般行政職の平均年齢および給与は 38.4 歳, 25 万 7400 円（1995 年 4 月 1 日現在）で, 全国町村平均を わずかに下回る程度である.このことを踏まえて，『地 方公務員給与の実態』に掲載されている町村一般行政職 員の平均給与の年齢カーブを見ると, おおよそ高卒者の 初任給が 15 万円前後, 大卒者の初任給が 18 万円前後と 推測される. 初任給の時点では他の村内事業所と大きな 差はないが, 明瞭な年功賃金カーブを描くため 50 歳頃 の平均月給額は 40 万円程度に達し, 壮年時の給与水準 は村内他産業を大きく上回る.

9 ）和良病院の開設・増設にあたっては村が条例によって 奨学金制度を設け，卒業後に和良病院で勤務することを 条件に学費を支給した. 現在は病院の経営悪化によって この制度は実施されていない．この制度によって薬剤師 や看護婦などの職員の相当数は村内出身者で充当し, 足 りない部分は専門学校などに直接募集することで必要な 人数を確保している. しかし医師だけは村内出身者では
確保することができず，現在は自治医大からの派遣医師 に依存せざるを得ない状態が続いている.

10）ただし中途採用に関しては各支店がそれぞれ独自に採 用できる.

11）制度的には月給制への移行も可能ではあるが, 現場労 務職員の中心を成す農家出身の中高年労働者が旧来のラ イフスタイルを踏襲して，好きなときに休みを取れる日 給・月給制の方を志向していることによる.

12）この事業所の事業主の 2 人の子供は共に建設関係の学 校に進学しているが, 今のところ跡を継ぐ意志はないと いう.

13）聞取り調查によれば, 女子の幹部職員の採用・抜てき を考えていないわけではないが, 現状では狭いムラ社会 の中の工場で職員間の人間関係のもつれが生じることを 恐れ，実施には至っていない，とのことである.

14）こうした男子と女子を明確に区別した労働力編成の実 態は, 中・南九州地方を事例とした友澤 (1989) で報告 されている.

15）調査の対象外となった就業者のうち, 筆者が確認して いるのは転勤のある公的・半公的事業所従業員 (10人), 前掲注 6 ) で挙げた商工会青年部未加入者 (5人), 従 業員規模 10 名未満の事業所の従業員 (7人), 調查を拒 否された農家 (1 人) である.

16)図 3 で用いられている「誘致工場」「中小工場」とい う表現はそれぞれ松田電機とそれ以外の村内製造業事業 所を指しており，これ以降の文章でも同様の定義で用い る. なお, この分類は第章第 3 節で職業構造を考察し た際の分類に従ったものである.

17）和良村において自衛隊への就職は将来的に地元定住を 考えている青年の一時的就職先として定着しており, そ の際に（1）公務員という職場の安定性，（2）大型自 動車などの資格の取得, という 2 点が就職を選択する主 要な理由となっている. 本アンケートでは自衛隊への就 職者が 4 例あるが，そのすべてが州村意志を持っており， 2〜4 年後に自衛隊を退団して帰村している. 退団後は 新規学卒ではない高卒者としての扱いを受けるため, 主 に労務職に就職する.

18）この状況は複数の聞取り調查によって確認されている.

\section{文 献}

安食和宏 1993. 北上山地の奥地山村集落における世帯の 構成とその再生産プロセス. 地理学評論 66A: 131-150. 安東誠一 1986. 『地方の経済学』東洋経済新報社.

岡橋秀典 1980. 奥飛驒山村・上宝村における非通年型雇 用の展開之農業・農民層の動向. 地理学評論 53: 511530.

岡橋秀典 1982. 山村における労働市場の構造变化と住民 
の所得形成一一愛知県豊根村の事例を中心に. 新潟大学 教養部研究紀要 13: 19-43.

岡橋秀典 1990. 「周辺地域」論と経済地理学. 経済地理学 年報 36: 23-33.

小木曽 豊 1986. 樑雪山村における挙家離村とその要因 一一新潟県東䅡城丘陵松之山町を例として. 人文地理 38: $250-264$.

斎藤光格・木曾敏行 1964. 長良川上流部の河川工事が周 辺村落に及ぼした影響について. 地理学評論 37: 163182.

篠原重則 1991. 『過疎地域の変貌亡山村の動向』大明堂. 自治体学会・第 4 分科会 1993. 島の自治之自立. 地域開 発 $350: 2-22$.

田代洋一 1993. 労働市場と農産物価格. 磯辺俊彦・常盤
政治・保志 恂編『日本農業論 (新版)』63-71. 有斐閣. 田島康弘・村上雅康 1985. 奄美における建設業の構造 一大和村を中心に. 鹿児島大学教育学部研究紀要 人 文社会科学編 37: 21-41.

友澤和夫 1989. 周辺地域における工業進出とその労働力 構造一一 - 南九州を事例として. 地理学評論 $62 \mathrm{~A}$ : 289-310.

藤田佳久 - 友国照久 1979. 十津川山村における土木建設 業の展開とその機能. 新地理 27(2): 27-39.

三浦. 真 1977. 山村における建設業の展開. 東京大学大 学院理学系研究科修士論文.

宮口侗妯 1978. 奥地山村における林業の展開と村落構造 一九州山地五家荘樅木部落における国 - 公営林業の進 展をめぐって． 東洋文化研究所紀要 76: 105-162. 
Geographical Review of Japan 71A-8 573-587 1998

\section{Migration and Occupation Careers of Young Male Employees in a Remote Mountainous Area: A Case Study of Wara Village, Gifu Prefecture}

Shin KAJITA (Graduate Student, Univ. of Tokyo)

Local economies in remote mountainous areas are characterized by dependence on the public sector. In this paper, the author examines the structure of occupations in a remote mountainous area by analyzing the migration and occupational careers of young male employees.

In the surveyed Wara village, male employees can be classified into three groups based on the age of first employment and educational background. The first group consists of officials of the municipality and the agricultural cooperative. This group is characterized by high wages and a wellestablished social welfare system. The employees in this group had the highest educational background and were the youngest when first employed. The second group consists of laborers of construction companies and factories that the local authority invited to the area. The employees in this group were almost as young as those in the first group when they were employed but had lower educational backgrounds. The third group consists of laborers in small factories, excluding those mentioned above. Most of the employees in this group were recruited at 30 years of age or older. Therefore the age of first employment in this group was by far the oldest of the three groups.

In contrast to these employees, the age at which employment started and the educational backgrounds of business founders, successors of well-managed companies, and professionals such as surveyors and physicians were variable.

Currently, only the municipal administration and the agricultural cooperative can employ young labor force participants as older employees retire.

Key words: remote mountainous area, migration and occupational career, public sector 